\title{
Does residents' perceived life satisfaction vary with tourist season? A two-step survey in a Mediterranean destination
}

This is the peer reviewed version of the following article:

Original:

Bimonte, S., Faralla, V. (2016). Does residents' perceived life satisfaction vary with tourist season? A twostep survey in a Mediterranean destination. TOURISM MANAGEMENT, 55, 199-208

[10.1016/j.tourman.2016.02.011].

Availability:

This version is availablehttp://hdl.handle.net/11365/1000535

since 2016-11-23T16:13:24Z

Published:

DOI:10.1016/j.tourman.2016.02.011

Terms of use:

Open Access

The terms and conditions for the reuse of this version of the manuscript are specified in the publishing policy. Works made available under a Creative Commons license can be used according to the terms and conditions of said license.

For all terms of use and more information see the publisher's website.

(Article begins on next page) 


\title{
Does residents' perceived life satisfaction vary with tourist season? A two-step survey in a Mediterranean destination
}

\author{
Salvatore Bimonte ${ }^{a}$ and Valeria Faralla ${ }^{b}$ \\ aUniversity of Siena, Department of Economics, \\ ${ }^{b}$ University of Eastern Piedmont
}

\section{A revised and updated version of this paper has been published in Tourism Management}

\section{http://authors.elsevier.com/a/1SexHxTbMbI77}

\begin{abstract}
Recent attention has been dedicated to the relationship between tourism and subjective well-being, however studies have mainly focused on the tourist side. Since residents are an indispensable partner for the success of any tourism program, understanding whether and how tourism affects residents' perceived life-satisfaction is a crucial issue. However, scant attention has been paid to this theme and the majority of studies are cross-sectional. Here we develop a two-step survey, conducted in a seaside resort before and during the tourist season to test for significant differences in residents' perceptions of tourism impact and overall life satisfaction. The results confirm the hypothesis that perceived tourism impact and life satisfaction vary with the tourist season, and that tourism has a hidden cost in terms of perceived life satisfaction.
\end{abstract}

Keywords: Happiness; residents' attitudes; tourism impact.

\section{Introduction}

Tourism is commonly acknowledged as a major driver of local economic growth and development. Macroeconomic data confirm this statement (WTO, 2014; WTTC, 2014). However, its fast past and forecasted growth, together with the many social and environmental 
problems caused by its often uncontrolled expansion, has led many authors to advise caution with regard to tourist development (Gursoy, Jurowski, \& Uysal, 2002; Northcote \& Macbeth, 2006; Saarinen 2006; Saarinen, Rogerson, \& Manwa, 2011)

Tourism was also recently acknowledged as one of the largest self-initiated commercial enterprises for creating happiness on the planet (Pearce, 2009; Pearce, Filep, \& Ross, 2011) but if this may seem to be true for those who travel, i.e. tourists (the guests), it is a questionable claim for those who receive tourists, i.e. local communities (the hosts).

There is currently an evident and surging interest in tourism as specific individuals' life satisfaction domains. Unfortunately, this new line of investigation has a discernible bias towards tourists. Various studies investigated the relationship between perceived life satisfaction and tourism. They have shown the contribution of tourism to individuals' well-being, testing the association between travel experiences and overall life satisfaction (Neal, Sirgy, and Uysal 2004; Neal, Uysal, and Sirgy 2007; Sirgy 2010; Sirgy et al. 2011), analyzing potential change in vacationers' feeling over the course of a vacation (De Bloom, Guerts, and Kompier 2012; Milan 1997; Nawijn 2010; Nawijn et al. 2013), comparing pre- and post-trip appraisals (Besser and Priel, 2006; Gilbert \& Abdullah, 2004; McCabe \& Johnson, 2013) or different types of tourist and activities (Bimonte \& Faralla, 2012; 2015).

On the contrary, only few papers have focused on residents or hosts (Kim, Uysal, \& Sirgy, 2013; Nawijn \& Mitas, 2012; Woo, Kin, \& Uysal, 2015). In other words, scant attention has been devoted to the relationship between development of tourism and residents' subjective well-being. This is unfortunate, because as emphasized in the literature on sustainable tourism, scholars increasingly agree on the fact that the success and sustainability of any tourist development crucially depend on acceptance of tourists and tourist-related plans by the local community (Bimonte, 2013; Bimonte and Punzo, 2011; Lee, 2013; Lepp, 2007; Pérez and Nadal, 2005). A shared vision of tourist development is required to avoid the sometimes disastrous effects of competition (Bimonte, 2008; Getz and Timur, 2005; Gursoy and Rutherford, 2004; Simmons, 1994).

According to Snaith and Haley (1999), "happy host" is fundamental to the successful development of tourism. Therefore, monitoring residents' attitude to tourist development and understanding how and whether tourism affect locals' perceived life satisfaction is a mandatory task for any policy maker and for the success of any tourist development plan. Only mutually beneficial development can prevent latent conflicts and opposition to tourism.

While much research and analysis on residents' attitudes to tourism and factors that may influence them have been carried out (e.g. Ap, 1990; 1992; Aguiló \& Rosselló, 2005; Andereck \& Vogt, 2000; Gursoy \& Kendall, 2006; Gursoy, Jurowski, and Uysal, 2002; Harrill, 2004), little attention has been paid to the relationship between attitudes and life satisfaction and, more in general, between tourism and overall life satisfaction (Kim, Uysal, \& Sirgy, 2013). Moreover, according to Sharpley (2014), scant attention has been paid to mainstream tourism destinations, such as the Mediterranean, and although residents' attitudes can change over time, few studies 
have taken a diachronic or longitudinal approach. Most just examined the effects of tourism at one point in time (Uysal et al., 2015)

The main objective of this paper is to contribute filling the above mentioned gap. To do this we developed an empirical analysis to investigate the issue. We report the findings of a two-step survey that measured changes in residents' perceived well-being with the start of the summer holidays. In particular, we explored whether (and how) the tourist season at the seaside affects residents' sense of well-being in various life domains and life satisfaction. The survey was carried out in Follonica, a mass tourist Mediterranean destination on the southern coast of Tuscany. A key question was whether the start of the peak tourist season had a negative impact on residents' self-reported happiness and which aspects (domains) of subjective well-being were affected in particular. We also sought to understand the specific and contextual factors that impinge on residents' subjective well-being assessments.

Although differences exist, the term well-being is often used as a synonym of subjective happiness, life satisfaction or quality of life (Woo, Kin, \& Uysal, 2015; Easterlin, 2004; McGillivray and Clarke, 2006; Veenhoven, 2007). Andereck and Nyaupane (2011) evidenced that more than 100 definitions for Quality of Lyfe exist in literature. Whatever the term, it is normally conceived as being the degree of how one views one's life as a whole, or some particular domain of one's life, as favorable (Powdthavee 2007, p. 5). Considering the aim of the paper, we will conform to this practice and use these terms interchangeably. We do not enter this debate or the theoretical debate on happiness. Useful insights may be found in some basic references (for example Woo, Kin, \& Uysal, 2015; Bruni and Porta 2007; Frey 2010; McCabe and Johnson 2013; Veenhoven 2007; Filep and Deery, 2010; Kahneman, 2003; Kahneman, Wakker and Sarin 1997).

\section{Literature review}

In the last decades, plentiful literature flourished on resident perceptions and attitudes of tourism. According to McGehee and Anderek (2004), it has become one of the most systematic and wellstudied areas of tourism. A number of reviews exist in the literature (Deery, Jago, \& Fredline, 2012; García et al., 2015; Harrill, 2004; Nunkoo, Smith, \& Ramkissoon, 2013; Sharpley, 2014; Uysal et al., 2015).

In line with claims of the Tourist Area Life Cycle (TALC) (Butler 1980; 2006) and the Irridex model (Doxey, 1975; Fridgen, 1991), most studies on residents' attitudes to tourist development show that locals are initially inclined to have positive attitudes to tourism, but their perception of impact and their level of acceptance tend to evolve as tourism increases (Teye, Sonmez, \& Sirakaya, 2002), though not necessarily in a deterministic and generalizable way (Gursoy, Chi, \& Dyer, 2010; King, Pizam, \& Milman, 1993; Monterrubio-Cordero, 2008). Many of these studies are framed in Social Exchange Theory (SET), their main aim being a cost-benefit appraisal to determine local citizens' inclination to participate in exchange with tourists and to 
endorse tourist development in their own community (Ap, 1992; 1990; Ap \& Crompton 1993; Gursoy \& Kendall 2006; Jurowski, Uysal, \& Williams, 1997; Kayat, 2002). They focus on the perceived impact of tourism, distinguishing socioeconomic, cultural and environmental impacts (Andereck and Vogt, 2000; Harrill, 2004; Jafari, 1986). Other influential intergroup theories, such as Integrated Threat Theory, the Unified Instrumental Model of Group Conflict and Intergroup Emotion Theory, have been largely overlooked (Ward and Berno, 2011).

Much of the literature has focused on identifying and measuring those variables that may influence the way in which tourism related impacts are perceived. Harrill (2004) identified three main categories: socioeconomic variables, spatial factors (i.e. availability of and proximity to tourism facilities and activities) and economic dependence. Others focused on personal factors, such as age, gender, income and length of residence. The latter were found to play a role in determining residents' attitudes to tourism (Perdue, Long, \& Allen, 1990). Males and older residents were found to be less concerned about impact and more tolerant to the presence of tourists in the area (Harrill and Potts, 2003; Mason \& Cheyne, 2000; Tomljenovic and Faulkner, 1999). Interestingly, length of residence was negatively correlated with positive attitude to tourism (Williams et al., 1995), even if the results were not completely constant in all studies (Allen et al., 1993). In general, mixed results have emerged when testing the correlations between these variables and resident attitudes towards tourism. Greater agreement exists on the relationship between residents' attitudes and two important variables, like closeness to tourist activities and economic dependence on tourism (Devine, Gabe, \& Bell, 2009; Gursoy \& Jurowski, 2002; Haley, Snaith, \& Miller, 2005; Martin, McGuire, \& Allen, 1998).

Depending on the specific host community, geographical area and type of tourist considered, a number of additional variables were also investigated, such as environmental and aesthetic impact, community attachment, services, as well as aspects impacting the quality of life, such as crime and overcrowding (e.g. Andereck \& Nyaupane 2011; Ap \& Crompton, 1998; Bimonte \& Punzo, 2011; Cavus \& Tanrisevdi, 2002; Cecil et al. 2010; Murphy, 1981; Smith \& Krannich, 1998). Variables describing the characteristics of visitors and the cultural background and moral values of host communities were found to be important (Monterrubio-Cordero, 2008; VargasSánchez, Porras-Bueno, \& Plaza-Mejía, 2011). All these factors have been categorized and analyzed in terms of extrinsic or intrinsic dimensions (Faulkner \& Tideswell, 1997).

The above aspects have also been analyzed in term of residents' response, rather than attitude, to tourist development and by segmenting resident in group with similar attitudes (Ap and Compton, 1993; Carmichael, 2000; Smith and Krannich, 1998). Unlike the TALC and Irridex models, these approaches do not assume homogeneous resident attitudes and reactions to tourist impact. Like other methods, they have been criticized because they fail to give a rigorous and comprehensive measure of attitudes (Harrill, 2004).

All these studies produced valuable insights into residents' attitudes to tourism, which are assumed to depend on the perception that residents have of costs and benefits (Stylidis et al., 2014; Teye, Sirakaya \& Sönmez 2002). In general, tourist development is acknowledged to have 
positive perceived economic impacts, but negative environmental and cultural impacts (Dickinson \& Lumsdon 2010). However, it is uncertain how these perceptions translate into variations in personal well-being. Efforts were made to look into the relationship between tourist development and well-being-related items (Allen et al;; 1993; Andereck \& Nyaupane, 2011; Crouch \& Ritchie, 1999; Jurowski, 1998; Lankford, 1994; Perdue et al., 1990; Pratt, McCabe \& Movono, 2015; Rivera, et al., 2015; Soutar \& McLeod, 1993; Williams \& Lawson, 2001; Woo, Kin, \& Uysal, 2015).

According to Kim, Uysal, \& Sirgy (2013: 529), no study focused on life satisfaction of residents as the ultimate dependent variable to establish the link between perceived impact of tourism and satisfaction with life domains in the destination community. In their study they tried to capture perceptions of tourism impact and relate these variables to well-established constructs and measures of quality of life. This was done by analyzing the way in which perceptions of tourism impact affects residents' sense of well-being in various life domains (i.e. material life, emotional life, safety) and, in turn, the latter influence the residents' perceived overall life satisfaction. Through a cross-sectional analysis, they evidenced that the strength of these relationships is moderated by the stage of tourism development. Drawing from the literature on positional goods, a term first coined by Hirsch (1977), Rivera et al. (2015) found that the relationship could also be mediated by social comparison.

Investigating these aspects and the direct link between tourism and residents' overall life satisfaction is also the aspect we tackle here. But, unlike cross-sectional studies that consider specific aspects of resident perceptions at a particular point in time, we run a two-step study to capture their evolution. Together with understanding the specific and contextual factors that impinge on residents' subjective well-being assessments, we also analyze which aspects (domains) of subjective well-being are affected by tourism related impacts. More important, we try to evidence how residents' attitudes to tourism evolve over time and whether and how life domains satisfaction and overall life satisfaction evolve with the start of tourism season.

The importance of understanding the relationship between tourism and residents' subjective well-being is manifold. First of all, combining two lines of investigation (into residents' attitudes to tourism and the economics of happiness), this study addresses an intriguing issue: is tourism beneficial for hosts and guests alike? That is, does tourism, as a life-satisfaction domain, also contribute to residents' happiness? Second, by assessing individuals' overall life satisfaction before and during the summer tourist season, it contributes a more rigorous and comprehensive measure of residents' perception of tourist impacts. Third, it identifies which of the various perceived impacts of tourism most affect residents' happiness. Fourth, it has potential benefits for planners of tourism: understanding the main determinants of life satisfaction may help prevent intra and inter-community conflicts and create a more hospitable atmosphere. Finally, it also contributes to the limited literature by assessing whether and how a constantly or temporally limited external factor (tourism) affects residents' perceived well-being. Since tourism transforms 
residents into hosts, our two-step investigation makes a contribution to the issue of whether people are more or less happy as residents than as hosts.

\section{Objectives, methods and results}

\subsection{The research hypotheses}

According to the bottom-up spillover theory life satisfaction is functionally related to satisfaction with all life's domains and sub-domains (e.g., satisfaction with family, social life, friendship, safety) (Kim, Uysal, \& Sirgy, 2013). The latter, in turn, are or may be influenced by others specific and contextual factors. Therefore, bottom-up spillover theory claims that individual's perceived well-being (on the top of hierarchy) is mostly determined by satisfaction with a variety of life domains and indirectly affected by others lower level factors.

Building on the above mentioned theory, our study aims to elicit residents' perceptions of tourism impact and verify to what extent they affect satisfaction with a variety of life domains and, ultimately, perceived well-being. But most importantly, the research addresses the following question: If tourism-related impacts are perceived by residents and these perceptions do influence their sense of well-being in various life domains and overall life, then could this influence vary depending on where the community is in the tourist season (out or during the tourist season)?

The hypotheses put forward in this paper are the following:

H1. Residents' perceived well-being is functionally related to the perception of tourism impact.

H2. Residents' perceptions of tourism impact vary with tourist season so do their satisfaction with contextual factors and, in turn, their perceived well-being.

\subsection{Study site and methods}

The survey was carried out in Follonica, a Mediterranean town in the northwest of the province of Grosseto, on the Gulf of Follonica (Figure 1). It is a mature national and international beach destination. Follonica offers a wide range of accommodation options, excluding luxury and five star hotels. Most visitors own a second home or rent private apartments; the others stay in hotels and other accommodation, such as serviced apartments. The town has a population of about 21,500 and receives around 65,000 tourists (528,000 night stays) a year (data provided by the Municipality of Follonica, reference year 2013). These numbers do not consider the thousands of second-home visitors. It is also worth noting that since the beginning of the Italian economic crisis, the number of tourists has substantially decreased. As a prevalently seaside destination, tourist flows are concentrated in the summer, particularly in July and August. 


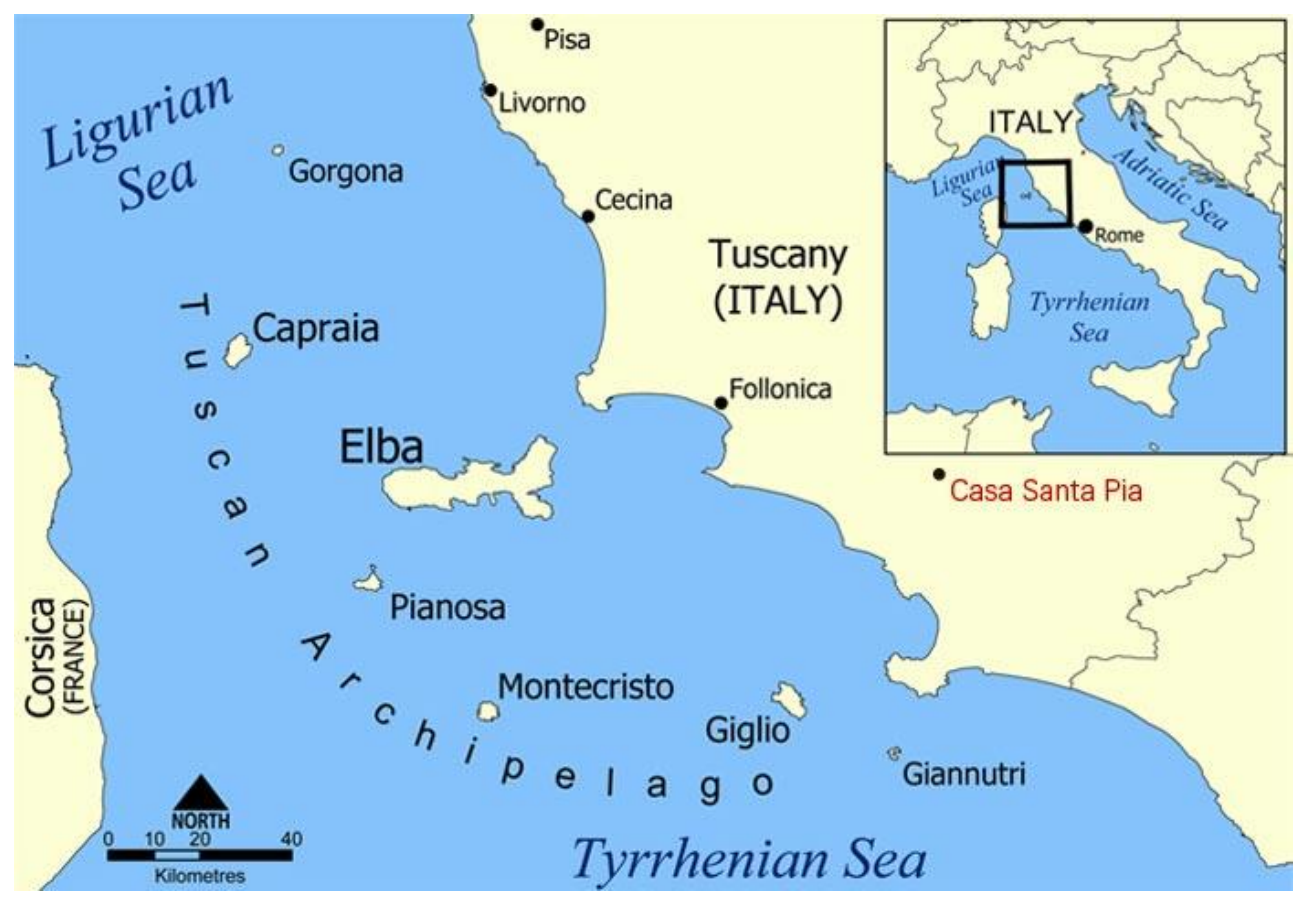

Figure 1: Follonica and the surrounding area

The survey followed a systematic sample procedure with $k=50$. A total of 329 individuals between 18 and 80 years of age were drawn from a population of 16,463 individuals, consisting of residents registered in the electoral list of the municipal office. Two surveys were carried out, administering the same questionnaire to the same sample of people. The first was conducted in May, just before the beginning of the tourist season, and the second in August at the peak of tourist season. While the reason for choosing August is obvious, the choice of May deserves some additional explanation. We had to select an off-season period for the first survey and avoid any structural change in the selected sample. The shorter the interval between the two surveys the greater the probability that the characteristics of the sample (income, marital status, job, etc.) remained unchanged. This was mandatory in order to separate and test for tourism effects.

Since about $31 \%$ of respondents were not available for the second interview, the final sample consisted of 225 individuals. The main aim of the survey was to test for statistically significant differences in perceived individual well-being and perceived tourist impact. This was done using the Wilcoxon signed-rank test. This test is used for analyzing two repeated measures at different time and when the data do not meet the requirements for a parametric test (Gang Li, 2012).

Answers were collected by telephone surveys. Before the interview, participants were told that they were participating in a study on happiness and that the questionnaire was not for commercial or advertising purposes but for research use only. Participants were also informed that the survey was strictly confidential and anonymous and that the data would only be released in aggregate form. Respondents were not compensated for their time. 
Participants were asked to answer to a number of questions. Following a common standard procedure in the empirical literature (Bruni \& Stanca, 2008; Frey \& Stutzer, 2002; OECD 2011; Veenhoven, 2009; 2007; World Values Survey, 2009), the first question was devoted to capture a preliminary assessment of their overall life satisfaction, as measured by a single-item response on a 10-point scale, ranging from 1 (unhappy) to 10 (very happy). Therefore, we made reference to the subjective dimension of well-being (psychological construct). As a non-observable attitude, researchers maintain that happiness can be studied by asking people how they feel with respect to one's life as a whole, or some particular domain of one's life (Powdthavee, 2007).

Since the main aim of the studies was to investigate the relative contribution of several factors to individuals' overall life satisfaction and which factors, if any, better explain its variability in time, additional aspects were investigated in two different periods. The questions were grouped in three sections. The first was aimed at evaluating satisfaction with aspects of life that have consistently been reported in the literature to be important determinants of happiness, e.g. work, health, relationship status and personal concerns. These domains are similar to those used in previous studies (e.g. Gilbert \& Abdullah, 2004; Frey \& Stutzer, 2002). The second section was devoted to evaluating residents' attitudes to tourism and their satisfaction with contextual factors, the quality of which may be affected by tourist development (e.g. public services, prices, quality of the urban environment). The latter aspects were also measured on a 10-point scale. The third section consisted of questions aimed at recording the socio-demographic details of residents.

The data were analyzed using R 2.13.2 software by R Foundation for statistical computing (R Development Core Team, 2010 - http://www.r-project.org/). After preliminary descriptive analysis of the data, the Wilcoxon signed-rank test (a paired difference test) was carried out. The McNemar test was applied for nominal scale variables. Then, considering the ordinal nature of the data, an ordinal logistic model (OLM) — which can be obtained as a special case of the general linear model (GLM) - was run to identify any correlation between the variables investigated in the survey (predictor variables) and self-reported happiness, which was treated as the response variable.

Since ordinal variables are coded as consecutive integers from 1 to 10 , it is tempting to analyze ordinal outcomes by linear regression model (LRM). However, an ordinal-dependent variable violates the assumptions of LRM and could lead to incorrect conclusions (McKelvey \& Zavoina 1975; Winship \& Mare 1984). Although many different models have been designed for ordinal outcomes, we used the logit version of the Ordinal Regression Model (ORM).

Ordinal logistic regression (OLR) was applied with the aim of highlighting the importance of different happiness determinants and differences between the two periods. In this model, once a reference variable has been selected, the variables' coefficient indicates the expected change in the response variable implied by a unit increase of the predictor (i.e. moving from one level to another of the variable). These coefficients are also called proportional odds ratios and should be interpreted as odds ratios of binary logistic regression. Specifically, a positive coefficient means 
that a unit change in the independent variable increases the likelihood of obtaining a higher score for the dependent variable, quantified by the coefficient (Long \& Freese, 2006).

\subsection{Sample characteristics and opinions}

The main descriptive characteristics of the sample are summarized in Table 1a and 1.b. The sample was composed of $45.3 \%$ females and $55.7 \%$ males of mean age 50.72 (s.d. 16.35) years. Most were married, had one child (mean 1,2, s.d. 0.9) and a high school diploma (median class). The percentage of workers $(17.2 \%)$ and retirees $(19.0 \%)$ was higher than other occupational categories. Declared net income was between $€ 5,001$ and $€ 15,000$ per year (median classes). About $73 \%$ of respondents were born in Follonica; $48 \%$ of the others moved to Follonica 10-20 years ago.

Table 1.a Sample and population by age group (\%)

\begin{tabular}{lrr}
\hline Age group & Sample & Population \\
\hline $18-25$ & 7.11 & 7.40 \\
$26-40$ & 22.22 & 20.91 \\
$41-60$ & 38.67 & 36.42 \\
$>60$ & 32.0 & 35.26 \\
\hline Mean & 50.7 & 51.59 \\
s.d. & 16.4 & 16.6 \\
kurtosis & -0.985 & -1.007 \\
skewness & -0.061 & -0.148 \\
\hline
\end{tabular}

\begin{tabular}{lc} 
Table 1.b Main socio-demographic characteristics & \\
\hline Gender & $54.7 \%$ male; $45.3 \%$ female \\
& $51.8 \%$ Married \\
Marital status & $32.6 \%$ Unmarried \\
& $15.6 \%$ Others \\
Number of children & (s.d. 0.97 ; kur. -0.300; sk. 0.445) \\
Level of education (median class) & High school diploma \\
& $17.2 \%$ Worker; \\
Work status & $19.0 \%$ Retirees \\
& $14.5 \%$ Retailers \\
Net income per year (median class) & $€ 5,001-15,000$ \\
Born in Follonica & $73 \%$ yes \\
If NOT: Years of residence (median class) & 10 - 20 \\
\hline
\end{tabular}

Table 2 summarizes the main descriptive statistics for perceived happiness, satisfaction with aspects of life and impact of tourism on contextual factors, the quality of which may be affected 
by tourism. In view of our aim, the table shows the results of the two surveys. Differences can be observed between the two periods. As expected, while nothing changed regarding satisfaction with aspects of people's own lives (family, income, sentimental situation, etc.), differences appeared for other items. Besides being less happy (decrease in median value from 8 to 7 ), residents seemed more responsive to tourist-related impacts. Compared to spring, in summer they answered that tourism aggravated overcrowding (increase in median value from 8 to 9) and damaged the quality of interpersonal relationships (increase in median value from 4 to 5). In these cases an increase corresponds to a worsening. For example, one question, scored on a 10point scale ranging from 1 (very little) to 10 (very much), was "In your opinion, how much do tourists and tourism affect interpersonal relationships?"

As for other aspects, though median values did not change, the percentage of high scores increased. In the case of "I like living in Follonica", the percentage of high scores declined and, consistently, the desire to move out of the town increased (14\% vs 18\%). "Summer as favorite season" also declined from $56 \%$ to $40 \%$.

Table 2: Time 1 vs. time 2: descriptive statistics of the sample

\begin{tabular}{|c|c|c|}
\hline Satisfaction with aspects of own life (median class) & Time 1 & Time 2 \\
\hline Happiness & 8 & 7 \\
\hline Income & 7 & 7 \\
\hline Family & 8 & 8 \\
\hline Sentimental situation & 8 & 8 \\
\hline Work & 7 & 7 \\
\hline Health & 8 & 8 \\
\hline Friendships & 8 & 8 \\
\hline \multicolumn{3}{|c|}{ Aspects of the home environment affected by tourism (median class) } \\
\hline Overcrowding & 8 & 9 \\
\hline Price increase & 5 & 5 \\
\hline Environmental quality & 7 & 7 \\
\hline Public services & 6 & 6 \\
\hline Interpersonal relationships & 4 & 5 \\
\hline Quality of life & 5 & 5 \\
\hline \multicolumn{3}{|l|}{ Others aspects related to tourism: Residents' opinions } \\
\hline Favorite season & Summer $(56 \%)$ & Summer $(40 \%)$ \\
\hline Like living in Follonica (median class) & 8 & 8 \\
\hline Want to move out of Follonica & $13.8 \%$ yes & $17.8 \%$ yes \\
\hline Increase tourist arrivals & $42.7 \%$ yes & $35.1 \%$ yes \\
\hline \multirow{2}{*}{ If NOT: } & $84.5 \%$ enough tourists & $69.2 \%$ enough tourists \\
\hline & $15.5 \%$ too many tourists & $30.8 \%$ too many tourists \\
\hline Conflict between tourists and residents & $24.4 \%$ yes & $30.2 \%$ yes \\
\hline Involved in tourism & $26.3 \%$ yes & $32.4 \%$ yes \\
\hline Tourism as important source of income & $100 \%$ yes & $99.1 \%$ yes \\
\hline
\end{tabular}

Moreover, while respondents considered tourism an important economic sector and source of income, they also thought it contributed to inter-community conflict. This belief was stronger in 
summer $(24 \%$ vs. $30 \%)$, when the number of people wishing for an increase in the number of arrivals declined (43\% vs. $35 \%$ ) and the percentage of those complaining of too many tourists increased.

Differences were tested for statistical significance by the Wilcoxon signed-rank test for paired observations. The McNemar test was applied for nominal scale variables. Levels of significance are shown in Tables 3 and 4. Non-significant results are also included. The results sustained previous findings.

Table 3. Time 1 vs. time 2: summary of Wilcoxon signed-rank test

\begin{tabular}{lc}
\hline Aspects of own life & p-value \\
\hline Happiness & $<0.05$ \\
Income & 0.3670 \\
Family & 0.9696 \\
Sentimental situation & 0.4325 \\
Work & 0.1580 \\
Health & 0.8828 \\
Friendships & $<0.05$ \\
\hline Aspects of home environment & \\
\hline Overcrowding & $<0.001$ \\
Price increase & 0.0556 \\
Environmental quality & $<0.001$ \\
Public services & $<0.05$ \\
Interpersonal relationships & $<0.05$ \\
Quality of life & $<0.001$ \\
Like living in Follonica & $<0.05$ \\
\hline
\end{tabular}

Table 4. Time 1 vs. time 2: summary of McNemar test

\begin{tabular}{ll}
\hline Aspects of home environment & p-value \\
\hline Wanting to leave Follonica & 0.1508 \\
Involved in tourism & 0.0736 \\
Tourism is an important source of income & $-*$ \\
If SO: Tourism as an irreplaceable source of income & 0.8137 \\
More tourists needed & 0.0754 \\
If NOT: Enough / too many tourists & $<0.01$ \\
\hline The test
\end{tabular}

\subsection{Residents and happiness}

As shown in the previous section, on a 10-point scale, respondents scored their happiness 8 in spring and 7 in summer. The percentage of residents scoring $\geq 8$ was $54.26 \%$ and $48.44 \%$ in spring and summer, respectively. This difference was statistically significant ( $\mathrm{p}$-value $<0.05$ by Wilcoxon signed-rank test for paired observations). Why this should be so is an intriguing 
question. We then applied ordinal logistic regression (OLR) to determine which variables were significant predictors of residents' happiness, taken as the reference variable. Regression was run separately for the two survey periods, looking for differences. The results are shown in Table 5.

Table 5. Happiness and residents: ordinal logistic regression (time 1 vs. time 2)

\begin{tabular}{|c|c|c|}
\hline Characteristics & $\begin{array}{c}\text { Time } 1 \\
\text { regression coefficient (SE) } \\
(p-v a l u e)\end{array}$ & $\begin{array}{c}\text { Time } 2 \\
\text { regression coefficient (SE) } \\
(p-\text { value })\end{array}$ \\
\hline \multicolumn{3}{|l|}{ Aspects of own life (base 1-6) } \\
\hline Income & $\begin{array}{r}1.9884(0.2781) \\
(<0.001)\end{array}$ & $\begin{array}{r}1.7914(0.2782) \\
(<0.001)\end{array}$ \\
\hline Family & $\begin{array}{r}2.4546(0.4494) \\
(<0.001)\end{array}$ & $\begin{array}{r}1.7640(0.4530) \\
(<0.001)\end{array}$ \\
\hline Sentimental situation & $\begin{array}{r}1.5649(0.3098) \\
(<0.001)\end{array}$ & $\begin{array}{r}0.9586(0.3019) \\
(<0.01)\end{array}$ \\
\hline Work & $\begin{array}{r}1.7087(0.2726) \\
(<0.001)\end{array}$ & $\begin{array}{r}1.5786(0.2621) \\
(<0.001)\end{array}$ \\
\hline Health & $\begin{array}{r}1.6204(0.3103) \\
(<0.001)\end{array}$ & $\begin{array}{r}1.5867(0.3008) \\
(<0.001)\end{array}$ \\
\hline Friendships & $\begin{array}{r}1.9217(0.5133) \\
(<0.001) \\
\end{array}$ & $\begin{array}{r}1.6290(0.3441) \\
(<0.001) \\
\end{array}$ \\
\hline \multicolumn{3}{|l|}{ Aspects of home environment } \\
\hline Overcrowding (base 1-6) & $\begin{array}{r}-0.3323(0.3400) \\
(0.3283)\end{array}$ & $\begin{array}{r}-0.8168(0.4568) \\
(<0.1)\end{array}$ \\
\hline Price increase (base 1-6) & $\begin{array}{r}-0.4564(0.2688) \\
(<0.1)\end{array}$ & $\begin{array}{r}-0.7450(0.2793) \\
(<0.01)\end{array}$ \\
\hline Environmental quality (base 1-6) & $\begin{array}{r}-0.3516(0.2440) \\
(0.1497)\end{array}$ & $\begin{array}{r}-0.3604(0.2460) \\
(0.1429)\end{array}$ \\
\hline Public services (base 1-6) & $\begin{array}{r}-0.3370(0.2587) \\
(0.1927)\end{array}$ & $\begin{array}{r}0.0478(0.2522) \\
(0.8497)\end{array}$ \\
\hline Interpersonal relationships (base 1-6) & $\begin{array}{r}-0.8069(0.3049) \\
(<0.01)\end{array}$ & $\begin{array}{r}-0.4706(0.2852) \\
(<.1)\end{array}$ \\
\hline Quality of life (base 1-6) & $\begin{array}{r}-0.8682(0.3367) \\
(<0.01)\end{array}$ & $\begin{array}{r}-1.1062(0.2859) \\
(<0.001)\end{array}$ \\
\hline Like living in Follonica (base 1-6) & $\begin{array}{r}2.1110(0.3842) \\
(<0.001)\end{array}$ & $\begin{array}{r}1.5576(0.3222) \\
(<0.001)\end{array}$ \\
\hline
\end{tabular}

In line with the results of other studies (Diener \& Fujita, 1995; Diener \& Lucas, 1999; Frey \& Stutzer, 2002; Lyubomirsky, Tkach, \& Dimatteo, 2006; Murrell, Salsman, \& Meeks, 2003; Rivera, et al., 2015; Oishi et al., 1999; Taylor, Funk, \& Craighill, 2006), analysis showed that residents' happiness was influenced by a wide range of material elements, namely, aspects of the own life such as income and work, but also by non-material aspects such as health, family, friendships and sentimental situation, in both periods. The determinants were exactly the same in both periods, as expected, suggesting that the preference structure did not change and that these determinants did not depend on the survey period. Since satisfaction with the variables found to be determinants of residents' happiness did not change in time (same median class and almost equal frequency distribution), the reason for lower perceived happiness in the second period had 
to depend on other factors. In our opinion, a plausible factor is the start of the tourist season, with all its implications.

We therefore tested for relationships between residents' satisfaction with life and aspects of the home environment considered to be affected by tourism. As highlighted in Table 5, all aspects except environmental quality and public services showed significant differences, as expected.

These results indicate that aspects of the home environment impinged on perceived satisfaction with life. Their impact was stronger in the second period. Indeed, while certain tourist impacts were only presumed in the first period, in the second they were truly experienced and perceived. Overcrowding, which was not significant in the first period, proved to be significant in the second. The significance, together with the magnitude of coefficients, also increased for "price increase" and "quality of life". As expected, those who liked living in Follonica were comparatively less likely to be happy in the second period. In fact, as stated above, the coefficients were interpreted as odds ratios of binary logistic regression. Specifically, a negative coefficient means that a unit change in the independent variable increases the likelihood of obtaining a lower score for the dependent variable by the amount of the coefficient. This result may be interpreted together with the above mentioned aspects. In fact, the negative impact of tourism on perceived well-being manifests as reduced pleasure of living in Follonica and increased desire to move out of the town.

As for "interpersonal relationships", its coefficient was as we expected, but in the second period, its significance and magnitude were lower. This may depend on two issues: the negative impact that tourism has on interpersonal relationships according to residents (median class 4 and 5) and residents' high satisfaction with their personal relationships, i.e. family, sentimental situation, friendships (all with a median class score of 8 in both periods).

\subsection{Discussion of the results}

The main findings of our research may be summarized as follows: while satisfaction with aspects of life did not change, satisfaction with aspects of the home environment deteriorated. According to residents, this depended mainly on tourism. Happiness also decreased, though its determinants turned out to be the same in both periods. This means that residents' preference structure did not change, corroborating the validity of our method. In fact, when choosing the period to carry out the surveys, one of our goals was to prevent any structural change in the sample.

Given the short interval between the two surveys, we can also assume that no variations in sample characteristics occurred (such as personal life aspects, i.e. job, income, etc.). We can therefore expect that the variation in individual happiness is due to contextual factors, i.e. the tourist season. Tourism would mediate the relationship between "aspects of own life" and

perceived happiness of residents through deterioration of the home environment. This is not only indicated by the decrease in subjective happiness of residents in the two periods, but also by the relationship between "aspects of the own life" and "home environment", and perceived 
satisfaction with life. Although they have the same sign, impacts were more pronounced in the second period; i.e. the relationship between determinants and individual well-being was damped when positive and reinforced when negative (see table 5).

Thaler \& Sunstein (2008) maintain that people's state of arousal varies over time (they may show dynamically inconsistent behavior). When in a cold state (in our case "off-season"), individuals do not appreciate how much their desires will be altered when they are in a hot state, i.e. under the influence of arousal (in our case "in peak season"). As a result, when in a cold state they do not appraise the effects that "arousal" produced by a hot state can have on their mood or evaluation. They can do it only when they are in that state. To use the Supreme Court Justice Potter Stewart's adage "I know it when I see it" (quoted in Thaler \& Sunstein, 2008, p. 41), i.e. when I have all the required information. In the language of economics, one can say that actual experience modifies agents' perceptions, changing their indifference curves and thus their appraisal (Bimonte \& Punzo, 2015). The discrepancies between predicted and observed appraisal may be explained in terms of ex-ante (expected) and interim (experienced) utility.

The interesting insight that our experiment brings out is that residents perceive tourism as a dual phenomenon. While aware of its major economic role and importance as a source of income, they admitted that it affected some aspects of their everyday life, worsening their perceived quality of life. The perceived impact increases with tourist season. A kind of "temporary" Easterlin tourist paradox emerges. Indeed, tourism is certainly one of the major drivers of Follonica's economy. All respondents considered it an important economic sector and source of income for the community. But, at the same time, it seems that, though temporary, it impinges on their quality of life. Therefore, tourism makes residents wealthier but, during the tourist season, less satisfied with their lives. In others words, the ultimate currency that residents spend for better material conditions is emotional. To state it in a slogan, we could say that wealthier hosts compensate for (temporary) less happy residents.

In general, this does not necessarily mean that people are actually less satisfied with their lives as a whole, but nevertheless they claim to be less happy. One may therefore think that contextual and temporary factors cause judgment bias: instead of assessing their lives as a whole (target question), they focus on the mood of the moment (heuristic question), and fit the answer to the original question by intensity matching. This is the essence of what Kaneman calls focusing illusion (Kahneman, 2011). Momentary bad humor impinges on people's perceived happiness.

Respondents probably realize that permanent aspects of their life are the same and that their happiness does not suddenly change because of tourism, but "System 1 (intuitive thoughts in contrast to System 2 deliberative thoughts) readily substitutes a small part for the whole. Any aspect of life to which attention is directed will loom large in a global evaluation" (Kaneman, 2011, p. 402). This could also depend on the fact that global measures involve the complex task of evaluating satisfaction with several personal life aspects, which are summed up in one answer. People might simplify the task by answering according to their affective state of the moment (Schwarz \& Strack, 1999). 
This is more relevant if a contrasting alternative that one is accustomed to is available (status $q u o$ ), as in the case of a tourist destination with high seasonality. In this case, transient events may be appraised more than enduring ones. The focusing illusion may induce people to misevaluate their present state of well-being.

\section{Conclusions}

There is growing consensus that people's well-being is not, or not exclusively, related to their possessions, at least once basic needs are satisfied. It is a fact that the blind pursuit of wealth and status is destroying our environment, interpersonal relationships and social capital. Broken social and environmental ties affect our quality of life and well-being (Kasser 2002).

Since Easterlin's (1974) seminal paper highlighting the diverging paths of economic growth and people's happiness, many studies have attempted to investigate the determinants of happiness. Particular attention has recently been devoted to leisure activities as a means to pursue a higher level of subjective well-being (e.g. Brajša-Žganec, Merkaš, \& Šverko, 2011; Diener et al., 1999; Iwasaki, 2007; Iwasaki et al., 2005; McCabe, 2009; Richards, 1999; Rodríguez, Látková, \& Sun, 2008). Tourism is a major leisure activity and increasingly acknowledged as an important determinant of happiness.

The literature on the topic has mainly focused on the demand side, i.e. the guest, but since tourism involves at least two communities, guest and host, and locals are an indispensable partner for the success of any tourist program (Bramwell \& Lane, 2000), understanding how and whether tourism also contributes to the host's life satisfaction is another crucial question (Uysal et al., 2015). This is exactly the question we addressed in the present study.

Following the bottom-up spillover theory, unlike the great majority of studies, based on cross-sectional analyses, we developed and reported the findings of a two-step survey aimed at measuring whether and which aspects (domains) of subjective well-being were particularly affected by the tourist season and whether this translated into changes in residents' perceived well-being. Our results show that residents perceived tourism as a dual phenomenon: on one hand they were aware that it is a driver of the local economy; on the other, they perceived it as a factor that impinges on some aspects of their everyday life, negatively affecting their well-being. What matters is that the perceived impact increases in the tourist season.

These results are somewhat particular. According to theory and empirical results, there is a positive relationship between happiness and income and other material conditions (Frey and Stutzer, 2000, 2002). Many studies demonstrate the positive link between tourism and local economic growth. As a consequence, communities at higher levels of tourism development should register higher life satisfaction. This is the case when cross-sectional or single (at one point in time) survey analyses are carried out (Meng et al., 2010; Rivera et al., 2015; Uysal et al., 2015), though this does not seem to be true for small island states (Pratt, McCabe \& Movono, 2015). When looking at evolution in time (diachronically), tourism may show detrimental effects on personal happiness and perceived conditions, as measured by subjective indicators. Subjective evaluations may not always be aligned with expectations based on objective indicators. Using the 
classification of Michalos (2003), Follonica seems a fool's hell in summertime, i.e. a destination rated high by objective economic indicators, but where people perceive living conditions in their communities as poor.

Understanding whether and why this happens could be useful for local planners and policy makers. This is important for at least two reasons: first, support of the host community is considered fundamental for tourism to thrive (Bimonte, 2013; Bimonte \& Punzo, 2011; Jurowski \& Gursoy, 2004; Lepp, 2007; Pérez \& Nadal, 2005) and happy hosts are certainly more prone to support tourist development (Snaith and Haley, 1999); second, the overall purpose of tourism is (should be) to enhance the quality of residents' lives. Happy hosts would also enhance the experience of tourists.

Monitoring subjective well-being patterns is a way to evaluate contextual factors and policies. Destination managers who only consider material indicators (e.g. jobs, income, arrivals etc.) may miss valuable information about what truly matters for a community. Indices to monitor residents' well-being should be used in combination with other more traditional indicators (Riveira et al., 2015; Uysal et al., 2015). This is particularly valuable when tourist development impinges on the various groups of stakeholders differently (i.e. people economically dependent on tourism vs independent) (García et. al., 2015; Uysal et al., 2015). In these cases, while objective indicators improve, individual' well-being (or at least that of some individuals) may worsen, because of inter-groups comparison that may cause envy and/or conflicts.

Equitable and shared tourist development may contribute to enhancing residents' perceived quality of life and prevent latent conflicts. Towards this aim, partnership approaches to tourism planning, such as local agenda 21 (Bramwell \& Lane, 2000; ICLEI, 2003; Shani \& Pizam, 2012), may help to reach agreement on tourism planning and development, whereas monitoring activities may help to evaluate processes and fine-tuning policies. Objective and subjective indicators have to be used in conjunction. In the case of the latter, more longitudinal (or at least diachronic) as well as cross-sectional measurements are required.

\subsection{Limitations and further research}

Like any other, this study is not lacking in limitations. It shares many of the limits of other such studies. The first is related to data collection. Budget limitations obliged us to restrict sample size and the periods covered. As for the dimension, whilst no distributional assumptions need to be made to use non-parametric tests, they require larger samples. A larger sample, surveyed over more than two periods (seasons), would have returned more reliable and clearer results.

Moreover, because each destination is unique, further research is required to test for different types of behavioral reactions and responses. More detailed analysis is required to confirm or reject our hypothesis: specifically, comparative analysis could be used to verify whether a seasonal effect exists or whether factors other than or besides tourism explain why people are less happy in summer. 
Despite these limitations, we believe that this research contributes to filling the gap in the research on tourism as a determinant of residents' happiness and reinforces its preliminary results. However, we believe that it would be worth exploring this line of investigation further, by replicating this study using different settings, i.e. destinations at different stages in the tourism development cycle (introduction, growth, early maturity, late maturity, decline) and with different levels of seasonality.

While aware of all the limits of our study, our approach may be useful for understanding the problems at stake and reinforce new line of research complementary to that on tourism as a determinant of visitors' happiness. Understanding the aspects most affected by tourism and how they impinge on residents' perceived happiness could help develop appropriate policies and prevent latent inter- and intra-community conflict.

Most studies on tourism have examined the effects of tourism development on residents' perceived well-being at one point in time. In this sense our study took a step in the right direction. However, the path is still long. In order to monitor residents' behaviors and responses to tourism multi-level and longitudinal analyses at different points in time and destinations are needed.

\section{References}

Aguiló, E. and Rosselló, J. (2005). Host Community Perceptions. A Cluster Analysis. Annals of Tourism Research, 32(4), 925 -940.

Allen, L., Hafer, H. R., Long, P. T., \& Perdue, R. R. (1993). Rural residents' attitudes toward recreation and tourism development. Journal of Travel Research, 31(4), 27-33.

Andereck, K. L., and G. P. Nyaupane. (2011). Exploring the Nature of Tourism and Quality of Life Perceptions among Residents. Journal of Travel Research, 50 (3): 248-60

Andereck, K., \& Vogt, C. (2000). The relations between resident's attitudes toward tourism and tourism development options. Journal of Travel Research, 39(1), 27-37.

Ap, J. (1990). Residents' Perceptions Research on the Social Impacts of Tourism. Annals of Tourism Research, 17 (4): 610-16.

Ap, J. (1992). Residents' perceptions on tourism impacts. Annals of Tourism Research, 19(4), 665-690.

Ap, J., \& Crompton, J. L. (1993). Residents' strategies in responding to tourism impacts. Journal of Travel Research, 32(1), 47-50.

Ap., J., \& Crompton, J. L. (1998). Developing and testing a tourism impact scale. Journal of Travel Research, 37(2), 120-130.

Besser, A., and B. Priel. (2006). "Models of Attachment, Confirmation of Positive Affective Expectations, and Satisfaction with Vacation Activities: A Pre-Post Panel Design Study of Leisure." Personality and Individual Differences, 41 (6): 1055-66.

Bimonte, S. \& Punzo, L.F. (2015). Tourist development and host-guest interaction: An economic exchange theory. Unpublished. Under revision

Bimonte, S. (2013). "Sustainable tourism: an interpretative and management paradigm". In: Tourism as a Tool for Development, P. Diaz (ed), WIT Press, Southampton, UK pp. 83-99 
Bimonte, S. (2008), The "tragedy of tourism resources" as the outcome of a strategic game A new analytical framework. Ecological Economics, 67, pp. 457-464

Bimonte, S. and Faralla, V. (2015), Happiness and Outdoor Vacations Appreciative versus Consumptive Tourists, Journal of Travel Research, Vol. 54(2) 179-192

Bimonte, S. and Faralla, V. (2012), Tourist types and happiness. A comparative study in Tuscany, Annals of Tourism Research, Volume 39, Issue 4, pp. 1929-1950

Bimonte, S. and Punzo. L.F. (2011), Tourism, residents' attitudes and perceived carrying capacity with an "experimental" study in five Tuscan destinations, International Journal of Sustainable Development, Vol. 14, Nos. 3/4, pp. 242-261

Brajša-Žganec, A., M. Merkaš, and I. Šverko. (2011). "Quality of Life and Leisure Activities: How do Leisure Activities Contribute to Subjective Well-Being?" Social Indicators Research, 102 (1): 81-91.

Bramwell, B., \& Lane, B. (2000). Tourism collaboration and partnerships. Politics, practice and sustainability. Clevedon: Channel View Publications.

Bruni, L., and L. Stanca. (2008). "Watching Alone: Relational Goods, Television and Happiness.” Journal of Economic Behavior \& Organization, 65 (3/4): 506-28.

Bruni, L., and P. L. Porta. (2007). "Introduction." In Handbook on the Economics of Happiness, edited by L. Bruni and P. L. Porta. Cheltenham, UK: Edward Elgar, pp. xi-xxxvii.

Butler, R. W. (2006). The concept of a tourist area life cycle of evolution: Implication for management of resources. In Butler, R. W. (ed.), The tourism area life cycle: Applications and modifications. Channel view publications: Clevedon.

Butler, R. W. (1980). The concept of a tourist area cycle of evolution: Implications for management of resources. Canadian Geographer, 24(1), 5-12.

Carmichael, B. (2000). A matrix model for resident attitudes and behaviors in a rapidly changing tourist area. Tourism Management, 21(6), 601-611.

Cavus, S., \& Tanrisevdi, A. (2002). Residents attitudes toward tourism: A case study of Kusadasi, Turkey. Tourism Analysis, 7(3-4), 259-268.

Cecil, A. K., Fu, Y.Y., Wang, S. and Avgoustis, S. (2010). "Cultural Tourism and Quality of Life: Results of a Longitudinal Study.” European Journal of Tourism Research, 3 (1): 54-66.

Crouch, G., \& Ritchie, J. R. B. (1999). Tourism, competitiveness, and societal prosperity. Journal of Business Research, 44(3), 137-152.

De Bloom, J., S. A. E. Guerts, and M. A. J. Kompier. (2012). Vacation (after-) Effects on Employee Health and Well-Being, and the Role of Vacation Activities, Experiences and Sleep. Journal of Happiness Studies, 14 (2): 613-33.

Deery, M., Jago, L., \& Fredline, L. (2012). Rethinking social impacts of tourism research: a new research agenda. Tourism Management, 33(1), 64-73.

Devine, J., Gabe, T., \& Bell, K. P. (2009). Community scale and resident attitudes towards tourism. The Journal of Regional Analysis and Policy, 39(1), 11-22.

Dickinson, J., and Lumsdon, L. (2010). Slow Travel and Tourism: Tourism, Environment and Development. London: Earthscan. 
Diener, E., and Lucas, R. (1999). "Personality and Subjective Well-Being." In Well-Being: The Foundations of Hedonic Psychology, edited by D. Kahneman, E. Diener, and N. Schwarz. New York: Russell Sage Foundation, pp. 213-229.

Diener, E., Suh, E. M., Lucas, R. E., and Smith, H. L. (1999). "Subjective Well-Being: Three Decades of Progress." Psychological Bulletin, 125 (2): 276-302.

Diener, E., and Fujita, F.. (1995). "Resources, Personal Strivings, and Subjective Well-Being: A Nomothetic and Idiographic Approach." Journal of Personality and Social Psychology, 68 (5): 926-35.

Doxey, G. V. (1975). A causation theory of visitor-resident irritants, methodology, and research inferences. Sixth annual conference proceedings of the Travel Research Association, San Diego, CA: Travel and Tourism Research Association, 195-198.

Easterlin, R. A. (2004). “The economics of Happiness.” Daedalus, 133 (2): 26-33.

Easterlin, R. A. (1974). "Does Economic Growth Improve the Human Lot? Some Empirical Evidence." In Nation and Households in Economic Growth: Essays in Honor of Moses Abromowitz, edited by P. A. Davis and M. W. Reder. New York: Academic Press, pp. 89125.

Faulkner, B., \& Tideswell, C. (1997). A framework for monitoring community impacts of tourism. Journal of Sustainable Tourism, 5(1), 3-28.

Filep, S., and M. Deery. (2010). "Towards a Picture of Tourists' Happiness." Tourism Analysis, 15 (4): 399-410.

Frey, B. S. (2010). Happiness: A revolution in Economics. Cambridge and London: The MIT Press.

Frey, B. S., and A. Stutzer. (2002). Happiness and Economics: How the Economy and Institutions Affect Well-Being. Princeton and Oxford: Princeton University Press.

Frey, B. S., \& Stutzer, A. (2000). Happiness, economy and institutions. The Economic Journal, $110,918-938$.

Fridgen, J. D. (1991). Dimensions of tourism. Lansing, MI: The Educational Institute of the American Hotel \& Lodging Association.

Gang Li (2012). "Statistical testing techniques". In: Dwyer, L., Gill, A. \& Seetaram, N. (eds.) Handbook of Research Methods in Tourism: Quantitative and Qualitative Approaches. Edward EldgarPublishing Limited, Cheltenham, UK.

García, F., Vázquez, A., \& Macías, R. (2015). Resident's attitudes towards the impacts of tourism. Tourism Management Perspectives, 13: 33-40.

Getz, D. and Timur, S. (2005), "Stakeholder involvement in sustainable tourism: balancing the voice", in W. F. Theobald (eds), Global Tourism, 3rd ed., Butterworth-Heinemann/Elsevier, New York, 230-247

Gilbert, D., and J. Abdullah. (2004). "Holiday Taking and the Sense of Wellbeing." Annals of Tourism Research, 31 (1): 103-21.

Gursoy, D., Chi, C.G. and Dyer, P. (2010). Locals' Attitudes toward Mass and Alternative Tourism: The Case of Sunshine Coast, Australia. Journal of Travel Research 49(3) 381-394 
Gursoy, D., \& Kendall, K. (2006). Hosting mega events: Modeling locals' support. Annals of Tourism Research, 33(3), 603-623.

Gursoy D., Rutherford D.G. (2004), Host attitudes toward tourism. An improved structural model, Annals of Tourism Research, vol. 31 n. 3, pp 495-516.

Gursoy , D., C. Jurowski, and M. Uysal (2002). "Resident Attitudes: A Structural Modeling Approach." Annals of Tourism Research, 29: 79-105.

Gursoy, D., \& Jurowski, C. (2002). Resident attitudes in relation to distance from tourist attractions. Available at: http://fama2.us.es:8080/turismo/turismonet1/economia\%20del\%20turismo/turismo\%20y $\% 20$ ocio/RESIDENT\%20ATTITUDES\%20IN\%20RELATIONS\%20TO\%20DISTANCE\%20FR OM\%20TOUSTIST\%20ATRACTIONS.PDF (Accessed July 15, 2013).

Haley, A. J., Snaith, T., \& Miller, G. (2005). The social impacts of tourism: A case study of Bath, UK. Annals of Tourism Research, 32, 647-668

Harrill, R. (2004). Residents' attitudes toward tourism development: A literature review with implications for tourism planning. Journal of Planning Literature, 18(1), 1-16.

Harrill, R., \& Potts, T. D. (2003). Tourism planning in historic districts: Attitudes toward tourism development in Charleston. Journal of the American Planning Association, 69(3), 233-244.

Hirsch, F. (1977). The Social Limits to Growth. London: Routledge \& Kegan Paul.

I.C.L.E.I., (2003). Tourism and local agenda 21: The Role of Local Authorities in Sustainable Tourism, Paris, UNEP.Iwasaki, Y. (2007). "Leisure and Quality of Life in an International and Multicultural Context: What Are Major Pathways Linking Leisure to Quality of Life?" Social Indicators Research, 82 (2): 233-64.

Iwasaki, Y., R. C. Mannell, B. J. A. Smale, and J. Butcher. (2005). "Contributions of Leisure Participation in Predicting Stress Coping and Health among Police and Emergency Response Services Workers." Journal of Health Psychology, 10 (1): 79-99.

Jafari, J. (1986). A systemic view of sociocultural dimensions of tourism. In President's Commission on American Outdoors, Tourism. Washington DC: United States Travel and Tourism Administration, 33-50.

Jurowski, C. (1998). A study of community sentiments in relation to attitudes toward tourism development. Tourism Analysis, 3(1), 17-34.

Jurowski, C. \& Gursoy, D., (2004). Distance effects on residents' attitudes toward tourism. Annals of Tourism Research, 31(2), pp. 296-312.

Jurowski, C., Uysal, M. and Williams, D.R. (1997). A theoretical analysis of host community resident reactions to tour ism. Journal of Travel Research 36, 2: 3-11

Kahneman, D. (2011). Thinking, fast and slow. Farrar, Straus \& Giroux, New York.

Kahneman, D. (2003). "A Psychological Perspective on Economics." American Economic Review, 93 (2): 162-68.

Kahneman, D., P. P. Wakker, and R. Sarin. (1997). "Back to Bentham? Explorations of Experienced Utility." Quarterly Journal of Economics, 112 (2): 375-405.

Kasser, T. (2002). The High Price of Materialism. Cambridge, MA: The MIT Press. 
Kayat, K. (2002). Power, social exchanges and tourism in Langkawi: Rethinking resident perceptions. International Journal of Tourism Research, 4(3), 171-191.

Kim, K., Uysal, M., and Sirgy, M.J. (2013). How does tourism in a community impact the quality of life of community residents? Tourism Management, 36, 527-540.

King, B., Pizam, A., \& Milman, A. (1993). Social impacts of tourism. Annals of Tourism Research, 20, 650-655.

Lankford, S. V. (1994). Attitudes and perceptions toward tourism and rural regional development. Journal of Travel Research, 32(2), 35-43.Lee, T. H. (2013). Influence analysis of community resident support for sustainable tourism development. Tourism Management, 34,37-46.

Lepp, A. (2007). Residents' Attitudes towards Tourism in Bigodi Village, Uganda. Tourism Management, 28: 876-85.

Long, J. S., and J. Freese. (2006). Regression Models for Categorical Dependent Variables using Stata. College Station, TX: Stata Press.

Lyubomirsky, S., C. Tkach, and M. R. Dimatteo. (2006). "What are the Differences between Happiness and Self-Esteem?" Social Indicators Research, 78 (3): 363-404.

Martin, B., McGuire, F., \& Allen, L. (1998). Retirees'attitudes toward tourism: Implications for sustainable development. Tourism Analysis, 3(1), 43-51.

Mason, P., \& Cheyne, J. (2000). Residents attitudes to proposed tourism development. Annals of Tourism Research, 27(2), 391-411.

McCabe, S. (2009). "Who Needs a Holiday? Evaluating Social Tourism." Annals of Tourism Research, 36 (4): 667-88.

McCabe, S., and S. Johnson. (2013). "The Happiness Factor in Tourism: Subjective Well-Being and Social Tourism." Annals of Tourism Research, 41 (April): 42-65.

McGehee, N., \& Anderek, K. (2004). Factors predicting rural residents' support for tourism. Journal of Travel Research, 43(2), 131-140

McGillivray, M., and M. Clarke. (2006). "Human Well-Being: Concepts and Measures". In Understanding Human Well-Being, edited by M. McGillivray and M. Clarke. Basingstoke, UK: Palgrave MacMillan, pp. 3-15.

McKelvey, R. D., and W. Zavoina. (1975). "A Statistical Model for the Analysis of Ordinal Level Dependent Variables.” Journal of Mathematical Sociology, 4 (1): 103-20.

Meng, F., Li, X., \& Uysal, M. (2010). Tourism development and regional quality of life: the case of China. Journal of China Tourism Research, 6(2), 164-182.

Michalos, A. C. (2003). Essay on the quality of life. Dordrecht: Kluwer Academic Publishers.

Milan, A. (1997). "The Impact of Tourism and Travel Experience on Senior Travelers' Psychological Well-Being.” Journal of Travel Research, 37 (2): 166-70.

Monterrubio-Cordero, J. C. (2008). Resident's perception of tourism: A critical theoretical and methodological review. Ciencia Ergo Sum, 15(1), 35-44.

Murphy, P. E. (1981). Community attitudes on tourism: A comparative analysis. Tourism Management, 2(2), 189-195. 
Murrell, S. A., N. L. Salsman, and S. Meeks. (2003). "Educational Attainment, Positive Psychological Mediators, and Resources for Health and Vitality in Older Adults." Journal of Aging and Health, 15 (4): 591-615.

Nawijn, J. (2010). "The Holiday Happiness Curve: A Preliminary Investigation into Mood During a Holiday Abroad." International Journal of Tourism Research, 12 (3): 281-90.

Nawijn, J., Mitas, O., Lin, Y.and Kerstetter, D. (2013). "How Do We Feel on Vacation? A Closer Look at How Emotions Change over the Course of a Trip." Journal of Travel Research, 52 (2): 265-74.

Nawijn, J. and Mitas O. (2012). Resident Attitudes to Tourism and Their Effect on Subjective Well-Being : The Case of Palma de Mallorca. Journal of Travel Research, 51(5) 531 -541

Neal, J. D., Uysal, M., \& Sirgy, M. J. (2007). The effect of tourism services on travellers' quality of life. Journal of Travel Research, 46, 154-163.

Neal, J. D., Sirgy, M. J., \& Uysal, M. (2004). Measuring the effect of tourism services on travelers' quality of life: Further validation. Social Indicators Research, 69, 243-277.

Nunkoo, R., Smith, S., \& Ramkissoon, M. (2013). Resident attitudes to tourism: a longitudinal study of 140 articles from 1984 to 2010. Journal of Sustainable Tourism, 21(1), 5-25.

Northcote, J., and J. Macbeth (2006). "Conceptualising yield in sustainable tourism management." Annals of Tourism Research, 33: 199-220

OECD (2011). "Compendium of OECD Well-Being Indicators." http://www.oecd.org/general/compendiumofoecdwell-beingindicators.htm (accessed October 5, 2012).

Oishi, S., E. Diener, E. Suh, and R. E. Lucas. (1999). "Value as a Moderator in Subjective WellBeing." Journal of Personality, 67 (1): 157-84.

Pearce, P. (2009). The Relationship Between Positive Psychology and Tourist Behavior Studies. Tourism Analysis, 14(1), pp. 37-48

Pearce, P. Filep, S. and Ross, G. (2011). Tourists, Tourism and the Good Life. Routledge, London, New York

Perdue, R. R., Long, P. T., Allen, L. (1990). Resident support for tourism development. Annals of Tourism Research, 17(4), 586-599.

Pérez, E., and Nadal, J. (2005). Host community perceptions: a cluster analysis. Annals of Tourism Research, 32(4), 925-941.

Powdthavee, N. (2007). "Economics of Happiness: A Review of Literature and Applications." Chulalongkorn Journal of Economics, 19 (1): 51-73.

Pratt, S., McCabe, S, \& Movono, A. (2015). Gross happiness of a 'tourism' village in Fiji. Journal of Destination Marketing \& Management, in press, available online.

Richards, G. (1999). "Vacations and the Quality of Life: Patterns and Structures." Journal of Business Research, 44 (3): 189-98.

Rivera, M., Croes, R., \& Lee, S. (2015). Tourism development and happiness: A residents' perspective. Journal of Destination Marketing \& Management, in press. 
Rodríguez, A., P. Látková, and Y.-Y. Sun. (2008). "The Relationship between Leisure and Life Satisfaction: Application of Activity and Need Theory." Social Indicators Research, 86 (1): 163-75.

Saarinen, J. (2006). "Traditions of Sustainability in Tourism Studies." Annals of Tourism Research, 38: 1121-40.

Saarinen, J., Rogerson, C., \& Manwa, H. (2011). Tourism and millennium development goals: Tourism for development? Current Issues in Tourism, 14(3), 201-203.

Schwarz, N., \& Strack, F. (1999). Reports of subjective well-being: Judgmental processes and their methodological implications. In Kahneman, D., Diener, E., \& Schwarz, N. (Eds). WellBeing: The foundations of hedonic psychology (pp. 61-83). New York: Russel Sage Foundation.

Shani, A., \& Pizam, A. (2012). Community participation in tourism planning and development. In M. Uysal, R. Perdue, \& M. J. Sirgy (Eds.), Handbook of tourism and quality-of-life research: Enhancing the lives of tourists and residents of host communities. Dordrecht, Netherlands: Springer, 547-564

Sharpley, R. (2014). Host perceptions of tourism: A review of the research. Tourism Management, 42, 37-49

Sirgy, M. J., and Su, C. (2010). "Toward a Quality-of-Life Theory of Leisure Travel Satisfaction." Journal of Travel Research, 49 (2): 246-60.

Sirgy, M. J., Kruger, P. S. Lee, D.J. and Yu, G. B. (2011). "How Does a Travel Trip Affect Tourists' Life Satisfaction?” Journal of Travel Research, 50 (3): 261-75.

Simmons, D.G. (1994) Community participation in tourism planning. Tourism Management, 15(20), 98-108.

Smith, M. D., \& Krannich, R. S. (1998). Tourism dependence and resident attitudes. Annals of Tourism Research, 25(4), 783-801.

Snaith, T., and Haley, A. (1999). Residents' opinions of tourism development in the historical city of York. Tourism Management, 20(5), 595-603.

Soutar, G., \& McLeod, P. B. (1993). Residents' perceptions on impact of the America's cup. Annals of Tourism Research, 20(3), 571-82.

Stylidis, D., Biran, A., Sit, J. and Szivas, E.M. (2014). Residents' support for tourism development: The role of residents' place image and perceived tourism impacts. Tourism Management, 45, 260-274

Taylor, P., C. Funk, and P. Craighill. (2006). “Are We Happy Yet?” Pew Research Center's Social and Demographic Trends, February 13, 2006, http://pewsocialtrends.org/2006/02/13/are-we-happy-yet/ (accessed September 28, 2013).

Teye, V., Sonmez, S. F. and Sirakaya E. (2002). "Residents' Attitudes towards Tourism Development." Annals of Tourism Research, 29: 668-88

Thaler, R., \& Sunstein, C. (2008). Nudge: Improving Decisions About Health, Wealth, and Happiness. New Haven and London: Yale University Press. 
Tomljenovic, R., \& Faulkner, B. (1999). Tourism and older residents in a sunbelt resort. Annals of Tourism Research, 27(1), 93-114.Uysal, M., Sirgy, M., Woo, E., \& Kim, H. (2015). Quality of life (QOL) and well-being research in tourism. Tourism Management, in press.

Vargas-Sánchez, A., Porras-Bueno, N., \& Plaza-Mejía, M. de los Á. (2011). Explaining residents' attitudes to tourism. Is a universal model possible? Annals of Tourism Research, 38(2), 460-480.

Veenhoven, R. (2007). "Measures of Gross National Happiness." Presentation at OECD Conference on Measurability and Policy Relevance of Happiness, Rome, April 2-3 (concept 10-3-2007). http://www.oecd.org/site/worldforum06/38303257.pdf (accessed October 5, 2012).

Veenhoven, R. (2009). "World Database of Happiness, Distributional Findings in Nations." Erasmus University Rotterdam. http://www1.eur.nl/fsw/happiness. Item O-SLW/c/sq/n/10/a (accessed October 5, 2012).

Ward, C. and Berno, T. (2011). Beyond social exchange theory: Attitudes Toward Tourists. Annals of Tourism Research, Vol. 38, No. 4, pp. 1556-1569

Williams, D. R., McDonald, C. D., Riden, C. M., \& Uysal, M. (1995). Community attachment, regional identity and resident attitudes toward tourism development. 26th Annual Conference Proceedings of the Travel and Tourism Research Association. Acapulco, Mexico: Travel and Tourism Research Association, 424-431. Available at: http://www.fs.fed.us/rm/value/docs/ttra95.pdf

Williams, J., \& Lawson, R. (2001). Community issues and resident opinions of tourism. Annals of Tourism Research, 28(2), 269-290.

Winship, C. and R. D. Mare. (1984). "Regression Models with Ordinal Variables." American Sociological Review, 49 (4): 512-25.

Woo, E., Kim, H. and Uysal, M. (2015). Life satisfaction and support for tourism development. Annals of Tourism Research, 50, 84-97

World Values Survey 1981-2008 Official Aggregate v.20090901. (2009). World Values Survey Association (www.worldvaluessurvey.org). Aggregate File Producer, Madrid: ASEP/JDS.

WTO (2014): “UNWTO Tourism highlights, 2014 edition”, Madrid.

WTTC (2014): "Travel and tourism economic impact 2014", London, UK. 